\title{
A Case Report of Rabies with Long Incubation: Importance in terms of Public Health
}

\author{
Uzun Inkübasyonla Seyreden Kuduz Olgusu: \\ Halk Sağlığı Açısından Önemi
}

\author{
Tuğba SARI1, Mesut SEÇER², Ebru AYDIN2, Mehmet YILMAZ³, Perihan ALKAN4, Yaşar AYIRKAN5, Hasan IRMAK6, irfan ŞENCAN7 \\ 1 Public Health Institution of Turkey, Department of Infectious Diseases, Ankara, Turkey \\ 2 Public Health Institution of Turkey, Department of Zoonotic and Vectors Diseases, Ankara, Turkey \\ ${ }^{3}$ Kocaeli Public Health Directorate, Division of Infectious Diseases, Kocaeli, Turkey \\ 4 istanbul Public Health Directorate, Division of Infectious Diseases, İstanbul, Turkey \\ ${ }^{5}$ Kars Public Health Directorate, Division of Infectious Diseases, Kars, Turkey \\ 6 Public Health Institution of Turkey, Vice-President of Infectious Disease Control Programs, Ankara, Turkey \\ 7 Public Health Institution of Turkey, Ankara, Turkey
}

Keywords: Rabies, rabies virus, rabies vaccine, horse community health, horse

Anahtar Kelimeler: Kuduz, kuduz virüsü, kuduz aşısı, toplum sağlığı, at

\section{Dear Editor,}

Rabies, caused by viruses in the genus Lyssavirus of the Rhabdoviridae family, is an acute zoonotic viral disease that leads to fatal encephalomyelitis in humans and many mammals despite the existence of effective prophylaxis ${ }^{[1]}$. It is estimated that 40,000-100,000 people die of rabies each year worldwide, which is much higher than official figures due to under-reporting ${ }^{[2]}$.

Herein, we discuss the importance of post-exposure prophylaxis and the risk rabies poses to public health in light of a mortal rabies case one year after exposure to a rabid animal.

A 15-year-old male patient was admitted to emergency service in Istanbul with hallucinations, clouding of consciousness, muscle spasms, seizures, and delirium. According to a history provided by the patient's family, he had been chased by a dog three days earlier, but there had been no contact with the dog. The patient did not exhibit hydrophobia, but upon detection of a 3-4 cm ecchymosis on the sole of his foot, he was given rabies vaccine (Abhayrab ${ }^{\circledR}$, Human Biologicals Institute, India) and equine rabies immunoglobin (RIG) (Equirab ${ }^{\circledR}$, Bharat Serums and Vaccines, India), $40 \mathrm{IU} / \mathrm{kg}$ by intramuscular injection. His general condition deteriorated and he was admitted to the intensive care unit two days later. With an initial diagnosis of meningeoencephalitis, studies were conducted to determine the encephalitis etiology. Cranial imaging tests (cranial magnetic resonance imaging and computed tomography) revealed no pathology; electroencephalography could not be performed; cerebrospinal fluid (CSF) biochemistry results showed protein: $52 \mathrm{mg} / \mathrm{dL}$, glucose: $101 \mathrm{mg} / \mathrm{dL}$ (simultaneous blood glucose: $124 \mathrm{mg} / \mathrm{dL}$ ); Brucella tube agglutination test (Wright) of CSF was negative; Gram and Ziehl Nielsen staining of CSF revealed no microorganisms; CSF and blood cultures were negative; and polymerase chain reaction (PCR) tests for Herpes simplex viruses 1 and 2, enterovirus, mumps, and varicella-zoster virus in CSF were negative. Due to a growing suspicion of rabies, specimens of serum, CSF, saliva, and neck hair follicle biopsy were obtained from the patient and sent to the Etlik Central Veterinary Control and Research Institute, where a diagnosis of rabies was confirmed by 
RNA extraction (MagNA Pure Compact System; Roche Diagnostics $\mathrm{GmbH}$, Mannheim, Germany) and reverse transcriptase-PCR (RTPCR) test (Verso 1-Step Hot-Start; Thermo Scientific, Foster City, CA, USA). The patient's family was subsequently questioned more thoroughly, and it was learned that in August 2015, he had been working as an animal caretaker in the village of Darboğaz in the Sevim district of the Kars province when one of his grandfather's horses contracted rabies after being bitten by a fox and was taken to the regional quarantine. However, because the patient insisted he had had no contact with the horse during that time, rabies prophylaxis was not administered. The patient was treated conservatively, but his general condition worsened. He died five days after hospitalization due to cardiorespiratory failure.

Since the patient resided in Kocaeli, field research for rabies was conducted in Kocaeli. It was determined that the area was urban and there were no rabies outbreaks among animals in the region.

Each year, approximately 200,000 people receive prophylaxis due to rabies exposure risk. Figure 1 shows numbers of rabies exposure risk and confirmed rabies cases in Turkey between 2000 and $2016^{[3]}$.

Analysis of rabies cases in our country over the last 20 years indicates that $93 \%$ of animal cases were in domestic animals, with dogs being the most common (59\%), and analysis of cases of rabies exposure risk demonstrates that the majority of animals involved in risky contact are stray domestic animals like cats and $\operatorname{dogs}^{[3,4]}$. As in the present case, transmission of rabies to humans also occurs via domestic animals which cannot be protected from wild animals.

Rabies is diagnosed (in animals and humans) by direct fluorescent antibody staining of tissue biopsy or necropsy samples. In humans, a skin sample taken from the nape of the neck just above the hairline is analyzed by direct fluorescent antibody test. Reverse

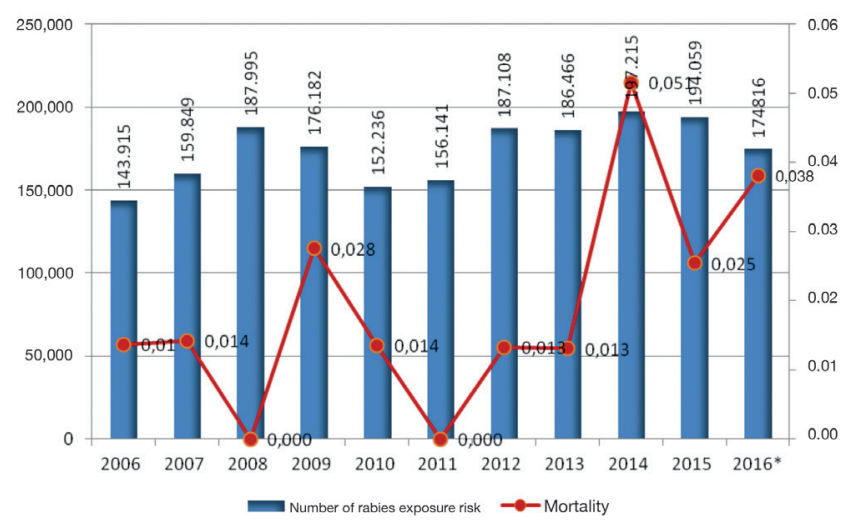

Figure 1. Annual distribution of cases of rabies exposure risk and mortality in Turkey

*Until November 29, 2016. The incidence values of mortality was calculated as the number of new cases / in the population in a certain period $\times 100000$
transcriptase-PCR is particularly useful for rapid diagnosis in human cases of suspected rabies. This test can be performed on CSF, saliva, or brain tissue ${ }^{[5]}$. The patient in the present case was diagnosed using RNA extraction and RT-PCR. The limitation of this report is that it was not possible to prove that the virus detected in the horse was the same as the virus detected in the patient. Our patient had no history of a clear bite or scratch from a rabid animal. Similarly, in five cases of confirmed rabies in Hong Kong between 1980 and 1984, two of the patients had been bitten by dogs, while the other three patients had no history of animal bite ${ }^{[6]}$.

The incubation period of the disease following a rabid animal bite is generally $14-90$ days. In $75 \%$ of cases, this period is between 20 and 90 days. Rabies virus infections with long incubation are rare. While the incubation period can be as short as four days, there have also been reports of rabies developing 27 months, six years, and even 19 years after exposure ${ }^{[7-9]}$.

Various factors influence the incubation period. The amount of viral inoculum and the site of inoculation are important. The amount of virus is inversely proportional to the incubation period. Incubation is shorter for bites in the head and neck area compared to those in peripheral region[1]. Despite the lack of exposure to a definite bite or scratch, our patient may have been infected while caring for a rabid animal through contact of saliva containing rabies virus with the patient's mucosa or an open wound or by inhaling aerosols containing the virus, and we believe this led to the prolonged incubation period.

The incubation period is also inversely proportional to the patient's age. The young age of our patient may also have contributed to the long incubation period ${ }^{[9]}$.

Following infection, the rabies virus stimulates the immune system. Despite the production of some antibody at the onset of disease, neutralizing antibodies usually appear one to two weeks after symptoms begin. However, the immune response is not sufficient to recover from the disease. Rabies may cause immunosuppression. Paradoxically, the incubation period is shorter in patients who have previously received a rabies vaccine. As our patient had never been vaccinated against rabies, that may also explain the long incubation period. Furthermore, the rabies virus can sometimes persist within macrophages and cause disease at a later time. This may explain the very long incubation period for some patients, as in our case ${ }^{[10]}$.

Death occurs an average of 18 days after symptoms appear. Recovery after the onset of clinical signs is extremely rare ${ }^{[11]}$. Patients' survival time depends on the medical care they receive. Our patient died five days after diagnosis.

Wound care and cleaning are cornerstones of rabies prevention. Ninety percent of rabies infections can be prevented in this 
way. Wounds can be effectively washed by applying plenty of water with some pressure into the wound and using a 20\% soap solution $^{[1]}$. Rabies prophylaxis is nearly $100 \%$ successful with modern tissue-culture vaccines and RIG administered at the proper dosage and in a timely manner ${ }^{[1]}$.

According to the Turkish Ministry of Health rabies field guide, prophylaxis should be administered as RIG +4 doses of vaccine (on days $0 ., 3 ., 7 .$, and 14.) or a "2-1-1" vaccine schedule if RIG is not available or could not be given ${ }^{[1]}$. In the present case, the patient received rabies prophylaxis in the dosage and schedule recommended by the rabies field guide.

In conclusion, this case illustrates the significant public health issue posed by risky contact with farm animals in addition to domestic animal bites in Turkey. When rabies is detected among animals belonging to individuals living in rural areas, these individuals should be evaluated for rabies prophylaxis even in the absence of definite animal contact. A detailed checklist should be prepared including questions about any contact with dead or rabid animals to ensure that a comprehensive history is obtained. In order to successfully treat patients with confirmed rabies or rabies exposure risk, these patients' records must be meticulously kept and the public must be educated about the importance of seeking immediate medical attention, proper wound care, and vaccinating their pets.

\section{Ethics}

Informed Consent: Consent form was filled out by family of our case.

Peer-review: Externally and internally peer-reviewed.

\section{Authorship Contributions}

Surgical and Medical Practices: T.S., M.S., E.A., M.Y., P.A., Y.A., H.I., I.Ş., Concept: T.S., M.S., E.A., M.Y., P.A., Y.A., H.I., I.Ş., Design: T.S., M.S., E.A., M.Y., P.A., Y.A., H.I., I.Ş., Data Collection or Processing: T.S., M.S., E.A., M.Y., P.A., Y.A., H.I., I.Ş., Analysis or Interpretation: T.S., M.S., E.A., M.Y., P.A., Y.A., H.I., I.Ş., Literature Search: T.S., M.S.,
E.A., M.Y., P.A., Y.A., H.I., I.Ş., Writing: T.S., M.S., E.A., M.Y., P.A., Y.A., H.I., I.Ş.

Conflict of Interest: The authors declared no conflict of interest related to the study described in this manuscript.

Financial Support: This study received no financial support from any institution or individual.

\section{References}

1. Büke $M$, Büke AÇ. Kuduz. İçinde: Topçu AW, Söyletir G, Doğanay $M$ (eds). İnfeksiyon Hastalıkları. 2nd ed. İstanbul: Nobel Tıp Kitabevleri, 2008:145367.

2. World Health Organization (WHO) | Rabies [Internet]. Last accessed date: 28 Haziran 2017. Available from: http://www.who.int/mediacentre/factsheets/ fs099/en/

3. T.C Sağlık Bakanlığı, Türkiye Halk Sağlığı Kurumu, Bulaşıcı Hastalıklar Kontrol Programları BaşkanYardımcılığı. Zoonotik ve Vektörel Hastalıklar Daire Başkanlığı. http://www.thsk.gov.tr/component/k2/353-istatikselveriler/zoonotik-ve-vektorel-hastaliklar-daire-baskanligi-istatiksel-verileri. html?highlight=YTox0ntp0jA7czo10iJrdWR1eil7fQ==

4. Sari T, Tulek N, Bulut C, Oral B, Tuncer Ertem G. Adverse events following rabies post-exposure prophylaxis: a comparative study of two different schedules and two vaccines. Travel Med Infect Dis 2014;12:659-66.

5. Kamolvarin N, Tirawatnpong $T$, Rattanasiwamoke $R$, Tirawatnpong $S$, Panpanich T, Hemachudha T. Diagnosis of rabies by polymerase chain reaction with nested primers. J Infect Dis 1993;167:207-10.

6. Wong TW, Chan PK, Fung KP. Human rabies in Hong Kong: a case review. Ann Acad Med Singapore 1987;16:663-5.

7. Hanna JN, Carney IK, Smith GA, Tannenberg $A E$, Deverill JE, Botha JA, Serafin IL, Harrower BJ, Fitzpatrick PF, Searle JW. Australian bat Lyssavirus infection: a second human case, with a long incubation period. Med J Aust 2000;172:597-9.

8. Grattan-Smith PJ, O'Regan WJ, Ellis PS, O'Flaherty SJ, McIntyre PB, Barnes CJ. Rabies. A second Australian case, with a long incubation period. Med J Aust 1992;156:651-4.

9. Bleck T, Rupprecht C. Rhabdoviruses, In Richman D, Whitley R, Hayden F (ed), Clinical Virology, Third Edition. ASM Press, Washington, DC. 2009. p 905-922.

10. Lafon M. Viral superantigens. In: Tomonari K (ed). Rabies virus superantigen. Boca Roton: CRC Press, 1997:151-70.

11. Karahocagil MK, Akdeniz H, Aylan O, Sünnetçioğlu M, Ün H, Yapıcı K, Baran Ai. Complete Recovery from Clinical Rabies: Case Report. Türkiye Klinikleri J Med Sci 2013;33:547-52. 